\title{
LEGAL FORMS OF STATE PARTICIPATION IN CIVIL RELATIONS
}

\section{Viktoriia Piddubna}

Ph.D., Associate Professor, Yaroslav Mudryi National Law University, Ukraine e-mail: vitafpdd@gmail.com, orcid.org/0000-0001-6532-9884

\section{Yulia Filonova}

Postgraduate Student, Yaroslav Mudryi National Law University, Ukraine e-mail: filonovaj1992@gmail.com,orcid.org/0000-0001-5250-5455

\section{Maciej Rudnicki}

Professor, Ph.D., Polonia University in Czestochowa, Interdisciplinary Faculty, Poland e-mail: kancelaria.rudnicki@poczta.fm,orcid.org/0000-0002-0019-3469

\section{Summary}

The article deals with the study of legal forms of state participation in civil relations. Today, an unresolved and complex issue is the existence of the legal personality of the state as a legal entity and state bodies for participation in property relations. The legal nature of the state and state bodies is analyzed. The article deals with the issues of direct participation or indirect participation of the state and state bodies. The legal forms of participation of the state in the creation of legal entities of public law, the creation of legal entities of private law, as well as the participation of the state in the activities of created legal entities are investigated. The article emphasizes that the types of legal entities of public law created by the state should be distinguished. State bodies vested with public authority and state institutions, which may have separate powers of authority. The article analyzes the signs of a state body and gives the author's conclusion about the participation of state bodies in civil circulation. The article examines the issue of the rights of legal entities of public law, in particular, the article emphasizes the need to replace the existing "quasi-speech" rights: the right of operational management and the right of economic management, as such that do not correspond to the principles of a market economy. It is proposed to replace these rights with market instruments in the form of organizational and legal forms of joint-stock and other companies, various types of contracts, private law structures of rights. The article in the historical aspect examines the legal approaches to the definition of the legal nature of the state. The issues of the concept and types of state bodies, their signs, features of the legal status and participation in civil legal relations are considered. The legal status of the legal entity of private law of PJSC Ukrzaliznytsia is analyzed and it is necessary that the creation and regulation of the activities of this legal entity takes place in accordance with the Law of Ukraine "On Joint Stock Companies". But there is another scientific position that PJSC "Ukrzaliznytsia" belongs to legal entities of public law. And since today there are no clear criteria for distinguishing between these legal entities, this issue should be clarified in order to resolve practical issues that arise in the activities of such legal entities.

Keywords: state, state bodies, legal entity of public law, subjects of public law, state joint stock companies

DOI: https://doi.org/10.23856/4527 


\section{Introduction}

Today in Ukraine there are no comprehensive theoretical studies of subjects of public law (the state, the Autonomous Republic of Crimea, territorial communities) as participants in civil relations. The concept of "state" in legal literature is used in both broad and narrow sense. So, in a broad sense, a state is understood as a power-organized society, in a narrow sense - a system of institutions of public power, a government apparatus. The state, unlike other subjects or participants in civil relations, has two main features: public power and sovereignty. In the legal literature regarding the participation of the state in civil relations, the following issues are debatable: 1) whether or not the state has civil legal capacity and legal capacity; 2) whether civil legal capacity and legal capacity are necessary to participate in civil circulation or whether public authority and sovereignty are sufficient prerequisites; 3) determination of persons and mechanisms through which the state participates in civil relations; 4) definition of the concept and characteristics of legal entities of public law; 5) the establishment of the specifics of the regulation of liability as a consequence of its participation in civil relations. Such famous scientists as I.V. Spasibo-Fateeva, V.I. Borisova, Yu.M. Dzera, O.O. Pervomaiskiy, Yu.N. Andreev, D.V. Pyatkov. The aim of the study is to clarify the legal nature of the state, the state has a civil personality, types of legal forms of state participation in civil relations. The following methods were used for research in the article: dialectical, logical, historical, comparative.

\section{Civil legal capacity of the state}

About whether the state has civil law and legal capacity, then in the science of civil law this issue is debatable and does not have an unambiguous solution. So, according to some scientists, the state can be considered a legal entity (Chirkin, 2007: 131), others deny this position (Golubtsov, 2008:82). Thus, an important and complex issue on the definition of the legal status of the state as a participant in civil relations is not resolved either at the doctrinal level or at the legislative level, which has as its consequence uncertainty with many areas of state participation in civil relations. At the same time, the state of Ukraine, the Autonomous Republic of Crimea, territorial communities, foreign states and other subjects of public law are participants in civil relations (Article 2 of the Civil Code of Ukraine). If these subjects are participants in civil relations, they must have legal capacity. So, in the opinion of Spasibo-Fateeva I.V. “... the state participates in civil legal relations, in particular property, not only in a static plane (property right) but also in a dynamic one (when objects of state property rights are alienated by means of their privatization). In this case, the question arises as to how the state participates in private relations? In our opinion, the only opportunity remains for her is to become the same subject of civil law" (Spasibo-Fateeva, 2006: 96-107). At the same time, the legal capacity and capacity of the state as a subject of public law has its own characteristics. These features are, firstly: the presence of public power and sovereignty.

\section{Historical preconditions for the formation of the concept of the state}

Even in Roman law, among the types of legal entities, a state is indicated that had legal capacity and took part in civil circulation in the form of a fiscal (treasury). Analyzing Roman sources, the legal literature indicates that without a direct definition of the law, the fiscal cannot claim any privileges, but is subject to common law, that is, it can be concluded that the state took part in civil circulation in the form of a fiscal (treasury), was equated to private individuals 
and had an equal legal status with other participants in civil turnover. But the fiscal (treasury) had certain privileges in comparison with other participants in the turnover (Baron, 1898: 72).

In Soviet times, views on the legal nature of the state did not have an unambiguous approach. So, according to A.V. Venediktov. the state is not a legal entity, a state body is a legal entity, at the same time, according to a state body, the state is the owner of the property due to this legal entity. The state can act as a legal entity in foreign trade, but this is more the exception than the rule. Bratus S.N. opposing this approach, he believed that the state is a legal entity in civil circulation and can take part in property relations as a treasury, and not only in foreign trade operations but also within the country (Bratus, 1947: 110).

This discussion regarding the legal nature and forms of participation in civil legal relations of the state and other subjects of public law continues today. As indicated in the legal literature, the definition of the legal nature and status of the state depends on the decision by national legislation of the issue of the model of state participation in civil relations. In modern civil law literature, two models of state participation in relations regulated by law are distinguished, these are "monistic" and "pluralistic". The monistic model understands cases when the state, with its participation in civil circulation, is recognized as a legal entity of public law. This model is typical for Western Europe and some CIS countries. The pluralistic model understands situations when the state, when participating in the appeal, is not recognized as a legal entity, and on behalf of the civil rights and obligations are acquired by state bodies acting in the appeal independently (Golubtov, 2008: 62). This model is typical for Ukraine, Russia and other CIS countries. Thus, the state acquires and exercises civil rights and obligations through state authorities within the limits of their competence established by law (part 1 of article 170 of the Civil Code). The state acts in civil relations on equal terms with other participants in these relations (part 1 of article 167 of the Civil Code). That is, the state can act in civilian circulation both directly and indirectly through state authorities.

In Western countries, state participation in civil relations has different models. So, in the United States and England, public law formations do not have the characteristics of a legal entity, and the bodies that act on behalf of the authorities are legal entities (authorities and administration). In the field of civil relations, state bodies of all branches of government are subordinate to the actions of contract law, and applies to individuals. In France, in civil law there is no concept of "public education", the concept of subjects of public law (state, local societies) is replaced by the concept of "public service" and "public organization". The state and local societies are endowed with the status of a legal entity and are subjects of exclusively administrative-legal relations; they are not participants in civil relations. Local authorities are limited in their powers to conclude economic contracts (Golubtsov, 2013: 62).

\section{Forms of state participation in civil relations}

In the legal literature, there are two main forms of participation in civil relations: the first form is the creation by the state of legal entities of public and private law (part 2, part 3 of article 167 of the Civil Code). This form is conventionally referred to as "constituent" or "constituent". The second legal form of participation of the state in civil relations is participation in the activities of legal entities of private law created by the state. This form is defined as "managerial" or "corporate. (Spasibo-Fateeva, 2020: 897).

According to the organizational and legal forms in which the state can create legal entities of public law, this list is open today. So, the state can create legal entities of public law (state enterprises, educational institutions, etc.) in cases and in the manner established by the 
Constitution of Ukraine and the law (part 2 of article 167 of the Civil Code). As correctly indicated in the doctrine of civil law, legal entities of public law can be created both in an administrative order (part 2 of article 81 of the Civil Code), and in the manner that is established in the law, that is, on the basis of a regulatory legal act. For example, in part 2 of Art. 125 of the Constitution of Ukraine states that "the court is formed, reorganized and liquidated by law." The state can create authorities, which are endowed with the status of a legal entity of public law. So, according to Part 1 of Art. 4 of the Law of Ukraine "On Central Executive Bodies" dated 17.03.2011, Ministries and other central executive bodies are legal entities of public law. The formation, reorganization and liquidation of ministries and other central executive bodies is carried out by the Cabinet of Ministers of Ukraine on the proposal of the Prime Minister of Ukraine (Article 5 of the Law of Ukraine "On Central Executive Bodies"). The procedure for creation, reorganization and liquidation was approved by the Resolution of the Cabinet of Ministers of Ukraine dated 20.10.2011 No. 1074.

Among the central bodies of executive power, which are legal entities of public law, the following are distinguished: ministries and other central bodies of executive power. The latter include the Antimonopoly Committee of Ukraine, the State Property Fund of Ukraine, the National Commission for State Regulation in the Spheres of Energy and Utilities, the State Committee for Television and Radio Broadcasting of Ukraine. After analyzing the law and regulations on these types of central executive bodies, it can be indicated that each of them performs a certain function of the state in a particular area of regulation of public relations. So, for example, the main tasks and functions of the Antimonopoly Committee of Ukraine are the implementation of state control over compliance with legislation on the protection of economic competition, prevention, detection and suppression of violations of legislation on the protection of economic competition (Article 3 of the Regulation "On the Antimonopoly Committee of Ukraine" dated 26.11.1993 No. 3659-XII). The main tasks of the State Property Fund of Ukraine include: implementation of state policy in the field of privatization, lease, use and alienation of state property, as well as in the field of state regulation of property valuation, property rights and professional appraisal activities (Article 4 of the Law of Ukraine "On the State Property Fund Ukraine "dated 09.12.2011 No. 1052-IX). The powers of the State Property Fund of Ukraine include the development of draft laws and other regulatory legal acts. Financing and material and technical support for the activities of ministries and other central executive bodies is carried out at the expense of the State Budget of Ukraine (Article 25 of the Law "On Central Executive Bodies"). As a rule, the activities of central executive authorities are directed and coordinated by the Cabinet of Ministers of Ukraine. In their activities, these bodies are guided by the Constitution of Ukraine, the laws of Ukraine, acts of the President of Ukraine and other acts of legislation of Ukraine. Regarding the simultaneous endowment of these bodies with the status of a legal entity of public law, then in the doctrine of civil law this issue is debatable. So today the very concept of the concept of "legal entity of public law" is only being formed, the essential features of this concept are being determined. As indicated in the literature, "the specificity of the legal personality of state bodies lies in the fact that they are not legal entities in civil circulation, but act as subjects with the rights of a legal entity, the scope of which is determined by the existing legal order, based on public tasks, goals, interests of the state, society and municipalities. ... There is another position regarding the relationship between the concepts of "state body" and "legal entity".

There is another position regarding the relationship between the concepts of "state body" and "legal entity". So, according to N.V. Kantor, the figure of a legal entity of public law will allow to qualify any action of a state body in civil circulation as an action of a corresponding 
public law entity and will create the personification of each individual body as a subject of private law to meet "administrative needs" (Kantor, 2005: 108-114).

In our opinion, state bodies are not legal entities in their pure form in accordance with the concept, which is enshrined in Art. 80 of the Civil Code of Ukraine: a legal entity is an organization created and registered in accordance with the procedure established by law. A legal entity is endowed with legal capacity and legal capacity, it can be a plaintiff and a defendant in court. Since, firstly, any state body is created and acts on the basis of either an administrative act or a regulatory legal act for the implementation of any function of the state or to satisfy the public interest; secondly, the rules on state registration do not apply to public authorities; thirdly, state bodies do not require the organizational and legal form established for other legal entities; fourthly, state bodies can act in civil circulation both on behalf of the subject of public law and on their own behalf; fifth, the principle of the freedom of contract is not manifested in the activities of the authorities within the limits of civil law; sixth, it is not the concept of legal personality that is characteristic of state bodies, but the concept of "competence" (Talapina, 2011:80-115). Thus, after analyzing all of the above, we can come to the conclusion that state bodies can be endowed with the status of a legal entity to participate in property relations.

The state, represented by its authorities, can also create such legal entities of public law as state unitary or commercial enterprises (Articles 73, 74) and state enterprises (Article 76 of the Civil Code of Ukraine). Such legal entities can be created only by state authorities (central and local) within the competence provided by the current legislation of Ukraine. The legal basis for the creation of such legal entities is a number of norms of the Civil Code, Civil Code, the Law of Ukraine "On the Management of Objects of State Property Rights". When these enterprises are created, the latter are endowed with certain property to carry out their activities. The owner of this property is the state of Ukraine, and therefore such property is transferred to a created legal entity or on the basis of the right of economic management (Article 136 of the Civil Code) or operational management (Article 137 of the Civil Code). On the right of economic management and the right of operational management, today the legal nature and consolidation of these rights are criticized by the majority of the scientific community. So, according to the Concept for the recodification of the Civil Code of Ukraine, it is planned to abandon these rights, since these rights are relics of the socialist past, artificially created for the needs of the nationalized economy. Quasi-speech rights of the Soviet era cannot be used in a market economy, when the state and other legal entities of public law act in civil relations on equal terms with other participants. Therefore, in the interests of economic growth, "Soviet" structures should be replaced by market instruments in the form of organizational and legal forms of joint-stock and other companies, various types of contracts, private law structures of rights (Civil Code Renewal Concept, 2020: 24-25).

The state can also take part in the civil turnover through the creation of state institutions. State institutions include, in particular, the following: health care institutions, educational institutions, centers and others. As it is correctly indicated in the legal literature, one cannot equate the concept of a state institution (institution, center) and a public authority. State institutions are not organs of state power, although in accordance with the law they can be vested with separate powers. The creation and operation of state institutions as legal entities of public law is regulated not by the Civil Code of Ukraine, but by the Constitution and laws of Ukraine. State institutions are not the owners of the property under their jurisdiction. The property of state institutions is state property. State institutions have state property on the basis of the right of operational management, and therefore, as a general rule, the decision on the disposal of this property is made by the state represented by the relevant authority. 
The state can create legal entities of private law (entrepreneurial societies, etc.) in cases and in the manner prescribed by the Constitution of Ukraine and the law (part 3 of article 167 of the Civil Code). As follows from this article, the list of organizational and legal forms of legal entities that a state can create is open. The most common organizational and legal form that is used by the state when creating legal entities of private law is a joint-stock company. So, for example, this can happen through corporatization (corporatization) of already existing enterprises. According to the Law of Ukraine dated 23.02.2012 No. 4442-VI "On the peculiarities of the formation of a joint stock company of public railway transport" it is indicated that the company is formed as a joint stock company, 100 percent of whose shares are fixed in state ownership, on the basis of the State Administration of Railway Transport of Ukraine, as well as enterprises, institutions and organizations of public railway transport, reorganized through a merger. The Charter of the Society is approved by the Cabinet of Ministers of Ukraine, the founder of the Society is the state represented by the Cabinet of Ministers of Ukraine. All of the above gave reason to scientists to classify PJSC "Ukrzaliznytsia" as legal entities of public law. We believe that the Public Joint Stock Company "Ukrzaliznytsya" is formed in accordance with the Law of Ukraine "On Joint Stock Companies". According to parts 2, 3 of the Law "On Joint Stock Companies" (hereinafter referred to as the Law), the activities of state joint stock companies and state holding companies, the sole founder and shareholder of which is the state represented by authorized state bodies, is regulated by the Law, taking into account the specifics provided for by special laws. The activities of the State Management Holding Company, state holding companies and state joint stock companies, the sole founder and shareholder of which is the state represented by authorized state bodies, is regulated by the Law of Ukraine "On Joint Stock Companies", taking into account the specifics stipulated by special laws.

\section{Conclusions}

Subjects of public law (state, Autonomous Republic of Crimea, territorial community, foreign states and others) in their activities implement public goals and objectives through indirect participation through state bodies. State authorities are classified as legal entities of public law. The peculiarity of the legal personality of which is that they have a dual legal nature: they are endowed with power and competence and at the same time have civil legal capacity to participate in civil relations. The legal forms of participation of the state in civil relations are the creation of legal entities of public law, among which are state authorities (central and local), state enterprises, educational institutions); the creation of private legal entities and take part in the activities of the latter.

\section{References}

Chirkin V.E. (2007) Yuridicheskoe litso publichnogo prava. Moskow: Norma. p. 131 [in Russian]

Golubtsov V.G. (2008) Publichno-pravovye sub"ekty v grazhdanskom prave. Opyt kompleksnogo issledovaniya. Perm: Perm State University. p. 82 [in Russian]

Baron Y. (1898) Sistema rimskogo grazhdanskogo prava. Moskow: Tipo-lithography Kushnerev and K. p. 72 [in Russian]

Spasibo Fateeva I.V. (2006) Dejaki problemy, pov'jazani z uchastju derzhavy Ukrajina $v$ cyviljno-pravovykh vidnosynakh. Kharkiv : Pravo, Bulletin of the Academy of Legal Sciences 
of Ukraine. p. 96-107. Retrieved from http://dspace.nlu.edu.ua/handle/123456789/5413 [in Ukrainian]

Bratus S.N. (1947) Yuridicheskie litsa v sovetskom grazhdanskom prave (ponyatie, vidy, gosudarstvennye yuridicheskie litsa). Moskow: Publishing House of Justice of the USSR. p. 110 [in Russian]

Golubtsov V.G. (2008) Uchastie Rossiyskoy Federatsii v imushchestvennikh otnosheniyakh, reguliruemykh grazhdanskim zakonodatel'stvom. Perm': NOU VPO West Ural Institute of Economics and Law. p. 62. Retrieved from http://predprin.psu.ru/images/citat/disser_vg_2008.pdf [in Russian]

Golubtsov V.G. (2013) Sistema i pravovoy status organov, vystupayushchikh ot imeni gosudarstva $v$ chastnopravovykh otnosheniyakh $v$ zakonodatel'stve zarubezhnykh stran. Perm. Perm University Bulletin. vol. 4 (22). Retrieved from cyberleninka.ru/article/n/sistema-i-pravovoy-status-organov-vystupayuschih-ot-imeni-gosudarstva-v-chastnopravovyh-otnosheniyah-v-zakonodatelstve-zarubezhny [in Russian]

Spasibo Fateeva I.V. (2020) Cyviljnyj Kodeks Ukrajiny: naukovo-praktychnyj komentar: Osoby: Kharkiv ECUS. p. 897 [in Ukrainian]

Kantor N.O. (2005) O gosudarstvennykh organakh kak yuridicheskikh litsakh publichnogo prava. Moscow Supreme Arbitration Court of the Russian Federation: Economy and Law. no 11. p. 108-114 [in Russian]

Talapina E.V. (2011) Publichnoe pravo i ekonomika: kurs lektsiy. Moscow: Walters Kluver. pp. 80-115 [in Russian]

Koncepcija onovlennja Cyviljnogho kodeksu Ukrajiny (2020). Kiev: Publishing house Artek. pp. 24-25 [in Ukrainian] 